\title{
イオンチャネル異常による致死性不整脈
}

\section{心房筋細胞における $\mathrm{AT}_{1}$ 受容体を介した緩徐活性型遅 延整流性 $\mathbf{K}^{+}$電流 $\left(\mathbf{I}_{\mathrm{Ks}}\right)$ の增大乙活動電位の短縮一心房細 動治療における $\mathrm{AT}_{1}$ 受容体遮断薬の有効性との関連一}

松浦 博*1 Dimitar P. Zankov*1, 2 尾松万里子*1 礒野高敬*3 豊田 太*1 丁 維光*1 堀江 稔*2

緩徐活性型遅延整流性 $K+$ 電流 $\left(I_{K s}\right)$ は活動電位プラト一相で活性化され活動電位持続時間 (APD) を決定する電流系の一つであり，ヒトを含む多くのほ乳類の心房筋や心室筋に存在 することが知られている. AT 1 受容体遮断薬は心房細動の発生に対して抑制効果があること が報告されているが，その電気生理学的機序は十分には明らかにされていない. 本研究の 目的は，心房筋細胞においてアンジオテンシン II (Ang II )によるI $\mathrm{k}_{\mathrm{s}}$ の修飾を検討し, 加え てそのAPD に及ぼす効果を明らかにすることとした．モルモット心房筋細胞に全細胞型 パッチクランプ法を適用して $I_{\mathrm{ks}}$ (voltage-clamp) ならびに活動電位 (current-clamp) を記録 した. Ang II ならびにその安定化誘導体であるSar'-Ang II は AT 1 受容体-Gタンパク質-ホ スホリパーゼC-プロテインキナーゼC系を活性化して $\mathrm{l}_{\mathrm{ks}}$ を増大させ，それに伴い APDを 短縮させることが明らかとなつた，本実験結果をヒ卜心房筋に外扦して考えると，AT 1 受容

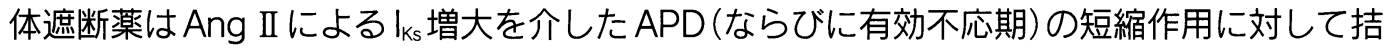
抗的にはたらくことが予想され，これがAT 1 受容体遮断薬のもつ心房細動に対する抑制効 果の背景となる電気生理学的機序の一つであると考えられた.

(心電図, $2007 ; 27: 145 \sim 153$ )

I .はじめに

\begin{tabular}{|c|c|}
\hline Keywords & $\begin{array}{l}\text { - 遅延整流性 } \mathrm{K}^{+} \text {電流 } \\
\text {-アンジオテンシン II } \\
\text { - } \mathrm{AT}_{1} \text { 受容体 } \\
\text { - 有効不応期 } \\
\text { ・ モモデリング }\end{array}$ \\
\hline
\end{tabular}

*1 滋賀医科大学生理学講座

（テ520-2192 滋賀県大津市瀬田月輪町）

$* 2$ 滋賀医科大学呼吸循環器内科

*3滋賀医科大学実験実習支援センター
ヒトをはじめ多くのほ乳類の心房筋や心室筋に存 在する緩徐活性型遅延整流性 $\mathrm{K}^{+}$電流 $\left(\mathrm{I}_{\mathrm{Ks}}\right)$ は，活動 電位のプラトー相で徐々に活性化され(外向き $\mathrm{K}^{+}$電 流を発生させ), 再分極相に大きく寄与する電流系 の一つである ${ }^{1) \sim 8}$. さらに, $\mathrm{I}_{\mathrm{Ks}}$ は $\beta$-アドレナリン受 容体 ${ }^{9)}$ １1)， $\alpha_{1}$-アドレナリン受容体 ${ }^{12)}$, P2Y-ATP受 容体 ${ }^{13)}$ 等の細胞膜受容体によって調節を受けており, これらの受容体アゴニストによる心筋活動電位持続

Potentiation of cardiac atrial $I_{K s}$ potassium current via $A T_{1}$ receptor by angiotensin II

Hiroshi Matsuura, Dimitar P. Zankov, Mariko Omatsu-Kanbe, Takahiro Isono, Futoshi Toyoda, Wei-Guang Ding, Minoru Horie 
時間 (APD)の制御にも密接にかかわっている.

心房細動 (atrial fibrillation, AF) は, 明らかな原 因を欠く場合(孤立性心房細動)に加えて，心不全や 高血圧性心疾患などにもしばしば合併することが知 られ, 最も頻度の高い不整脈の一つである. 加えて, 心房細動をいったん発症すると心房筋自体に心房細 動の再発もしくは持続が起こりやすくなるような機 能的もしくは組織学的変化が惹起されるため(電気 的ならびに構造的リモデリング) ${ }^{14), 15)}$, 心房細動は 発作型から持続型へ移行しやすく治療に難渋するこ とが多い. 心房細動の発生には心房筋の電気生理学 的性質の変化が密接にかかわっており，特にその APD (ならびにそれに依存する有効不応期)の短縮は 心房内にリエントリー回路の形成を可能にして心房 細動の発生に寄与すると考えられている ${ }^{16)}$. 近年行 われた家族性心房細動の遺伝子検索において, $\mathrm{I}_{\mathrm{Ks}}$ チャネルの pore-forming $\alpha$-subunit (KvLQT1)の発 現をコードする $K C N Q 1$ 遺伝子に機能獲得型 (gain of function)のミスセンス変異 (S140G)がみつかってお $\eta^{17)}, \mathrm{I}_{\mathrm{Ks}}$ チャネルの機能立進 (upregulation) が心房 筋有効不応期の短縮を介して心房細動の発症に結び つく可能性が示唆されている.

アンジオテンシン II (Ang II ) タイプ1 $\left(\mathrm{AT}_{1}\right)$ 受容 体遮断薬は心房細動の電気的除細動後の再発予防に 有効であることが報告されている ${ }^{18)}$.すなわち，ア ミオダロン投与群とアミオダロン + irbesartan投与 群との比較において併用群で有意に再発が少なく, さらにその効果の差は除細動後早期に顕著であるこ とが明らかにされた.しかし，この $\mathrm{AT}_{1}$ 受容体遮断 薬の心房細動に対する抑制効果に関しての電気生理 学的背景は十分には解明されていない.

本研究では, 心房筋細胞における Ang II $I_{\mathrm{Ks}} に$ 対する急性作用ならびにそれにかかわる細胞内機構 を検討し, 加えてその APDに及ぼす効果を調べた ${ }^{199}$. また，その実験結果に基づいて $\mathrm{AT}_{1}$ 受容体遮断薬の 心房細動治療における有効性の電気生理学的背景に ついても考察する.

\section{II. $A T_{1}$ 受容体刺激による $I_{\mathrm{ks}}$ の増大}

モルモット摘出心をコラゲナーゼ処理して単一心 房筋細胞を得た。全細胞型パッチクランプ法 (whole-cell patch-clamp method)を適用し, 細胞膜 電流ならびに膜電位を記録した，活動電位記録時の 細胞灌流液 (細胞外液)にはタイロード液を用いた。 その組成 $(\mathrm{mmol} / \mathrm{L})$ は, $\mathrm{NaCl} 140, \mathrm{KCl} 5.4, \mathrm{CaCl}_{2}$ 1.8, $\mathrm{MgCl}_{2}$ 0.5, $\mathrm{NaH}_{2} \mathrm{PO}_{4}$ 0.33, glucose 5.5, HEPES 5.0 で, $\mathrm{NaOH}$ にて $\mathrm{pH}=7.4$ に滴定した. $\mathrm{I}_{\mathrm{Ks}}$ 記録時に は，タイロード液にニソルジピン $(0.4 \mu \mathrm{mol} / \mathrm{L})$ およ びE-4031 (5 $\mu \mathrm{mol} / \mathrm{L})$ を添加した. 電極内液(細胞内 液) $(\mathrm{mM})$ は, K-aspartate $70, \mathrm{KCl} 50, \mathrm{KH}_{2} \mathrm{PO}_{4} 10$, $\mathrm{MgSO}_{4}$ 1.0, $\mathrm{Na}_{2}$-ATP 3.0, Li 2 -GTP 0.1, EGTA 5.0, HEPES 5.0 とし, KOHにて $\mathrm{pH}=7.2$ に調整した。

図1Aは，保持電位- $50 \mathrm{mV}$ から種々のテスト電 位に $2,000 \mathrm{msec}$ の脱分極パルスを与えて活性化した $\mathrm{I}_{\mathrm{Ks}}$ に及ほす Ang II $(1 \mu \mathrm{mol} / \mathrm{L})$ の効果を示す。なお， この脱分極パルスによって同時に活性化される L型 $\mathrm{Ca}^{2+}$ チャネル $\left(\mathrm{I}_{\mathrm{Ca} . \mathrm{L}}\right)$ および急速活性型遅延整流性 $\mathrm{K}^{+}$ チャネル $\left(\mathrm{I}_{\mathrm{Kr}}\right)$ はそれぞれ, ニソルジピン $(0.4 \mu \mathrm{mol} / \mathrm{L})$ およびE-4031 $(5 \mu \mathrm{mol} / \mathrm{L})$ を細胞灌流液 (タイロード 液)に加えることにより完全にブロックした．脱分 極パルス中にみられる時間依存性の外向き電流の増 大は $\mathrm{I}_{\mathrm{Ks}}$ の活性化過程をあらわす。一方, $-50 \mathrm{mV}$ (保持電位) に戻したときに発生する末尾電流 (tail current) は $\mathrm{I}_{\mathrm{Ks}}$ の脱活性化過程を反映する. Ang IIに より脱分極パルス中の外向き電流および保持電位に 戻したときの tail currentはいずれも増加しており, Ang IIにより $\mathrm{I}_{\mathrm{Ks}}$ が増大したことがわかる．種々の濃 度 $(1 \sim 1000 \mathrm{nmol} / \mathrm{L})$ の Ang II による $\mathrm{I}_{\mathrm{Ks}}$ の増加率を tail currentの変化から求め, それを Ang II 濃度に対 してプロットした(用量反応曲線，図1B)。両者の 関係を Hill式にフィットして求めた半最大活性化濃

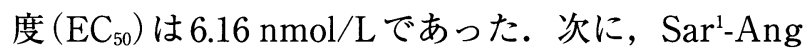
II の $\mathrm{I}_{\mathrm{Ks}}$ に及ぼす効果を調べた。なお，Sar-Ang II は Ang II の第一番目のアミノ酸であるアスパラギン酸 (Asp) をサルコシン ( sarcosine, 天然タンパク質に 
A

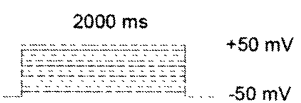

Control

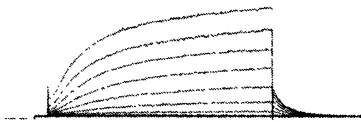

Ang $\| 1 \mu \mathrm{mol} / \mathrm{L}$

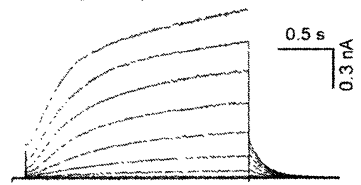

C

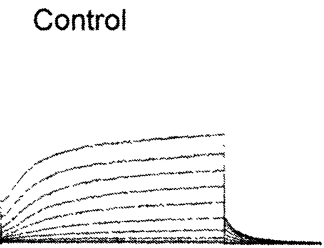

Sar ${ }^{1}$-Ang $\| 100 \mathrm{nmol} / \mathrm{L}$

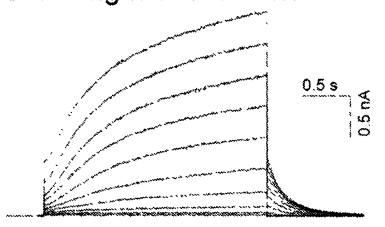

B

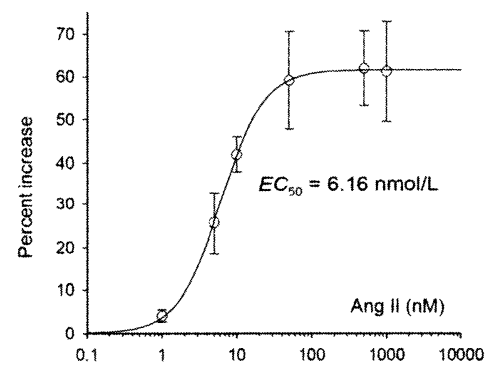

D

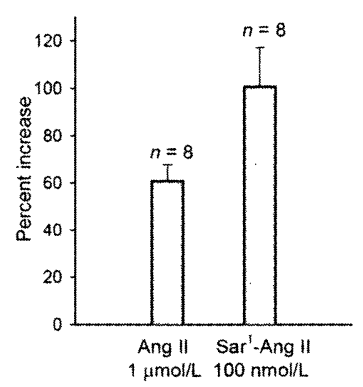

図 1 Ang II およびSar'-Ang II による $\mathrm{I}_{\mathrm{ks}}$ の増大

A ：Ang IIによる $\mathrm{I}_{\mathrm{Ks}}$ の増大. $\mathrm{I}_{\mathrm{Ks}}$ は保持電位 $-50 \mathrm{mV}$ から $2,000 \mathrm{msec}$ の脱分極パルスを $-40 \mathrm{mV}$ から $+50 \mathrm{mV}$ の範囲に $10 \mathrm{mV}$ ステップで与えて活性化した(inset参照).コントロール時(左)ならびに $1 \mu \mathrm{M}$ Ang II (右)投与下での電流記録を示す.

B : Ang II よよる $\mathrm{I}_{\mathrm{Ks}}$ の増大作用の用量反応曲線. $+30 \mathrm{mV}$ のテスト電位における tail currentの増加率 を Ang II濃度に対してプロットした。曲線はHill式を示す $\left(\mathrm{EC}_{50}=6.16 \mathrm{nmol} / \mathrm{L}\right)$.

C : Sar'-Ang II $(100 \mathrm{nmol} / \mathrm{L})$ による $\mathrm{I}_{\mathrm{Ks}}$ の増大. パネル A と同じパルスプロトコールで $\mathrm{I}_{\mathrm{Ks}}$ を活性化した.

$\mathrm{D} ：+30 \mathrm{mV}$ のテスト電位における Ang II と Sar $^{1}$-Ang II による $\mathrm{I}_{\mathrm{Ks}}$ の增加率 (Ang II , $60.8 \pm 6.8 \%$; $\mathrm{n}=8$, Sar-Ang II , $100.7 \pm 16.4 \% ; \mathrm{n}=8)$.

〔文献 19)より引用改変〕

は含まれていないアミノ酸の一つでN-メチルグリシ ンにあたる）に置換してアミノペプチダーゼ (aminopeptidase)に対して安定な特性をもつように したAng II のアナログである．図1Cに示すように， Sar-Ang II (100 nmol/L) も $\mathrm{I}_{\mathrm{Ks}}$ に対して増大作用を及 ぼし， + $30 \mathrm{mV}$ のテスト電位で計測された増加率は $100.7 \pm 16.4 \% ； \mathrm{n}=8$ (図 1D)であった。これはAng II $(1 \mu \mathrm{mol} / \mathrm{L})$ による増加率 $(60.8 \pm 6.8 \% ; \mathrm{n}=8)$ よ り大きかった(図1D).

次に, Ang II およびSar'-Ang II による $\mathrm{I}_{\mathrm{Ks}}$ の増大 効果にかかわる細胞内シグナル伝達機構について検 討を行った.アゴニストとして，より大きな増大反 応を引き起こす Sar ${ }^{1}$-Ang II を用いた (図 1参照).
図2Aに示すように，選択的 $\mathrm{AT}_{1}$ 受容体遮断薬であ るバルサルタン $(1 \mu \mathrm{mol} / \mathrm{L})$ を細胞灌流液に加えると Sar'-Ang II (100 nM)の $\mathrm{I}_{\mathrm{Ks}}$ に及ほす増大効果はほと んど消失した. 多数例の検討の結果, Sar ${ }^{1}$-Ang II $(100 \mathrm{nM})$ の $\mathrm{I}_{\mathrm{Ks}}$ に対する増加率はバルサルタン非存 在下 (コントロール)で $100.7 \pm 16.4 \% ; \mathrm{n}=8$, バル サルタン存在下で $15.7 \pm 4.6 \% ; \mathrm{n}=8$ であった (図2B)。この実験結果より, Sar'-Ang II による $\mathrm{I}_{\mathrm{Ks}}$ の増大反応には $\mathrm{AT}_{1}$ 受容体がかかわっていると考え られた。

$\mathrm{AT}_{1}$ 受容体は $\mathrm{Gq}$ タンパク質-ホスホリパーゼ C (PLC)-プロテインキナーゼC(PKC)系を活性化して, Ang II の主に急性作用の発現にかかわることが心筋 
A

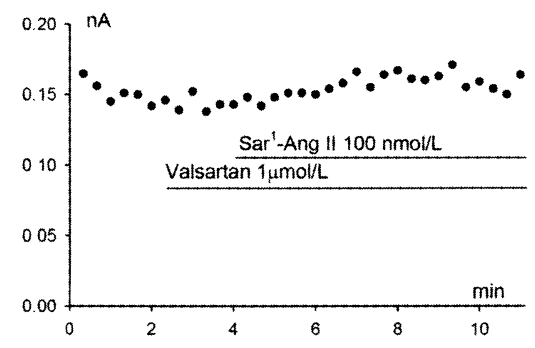

B

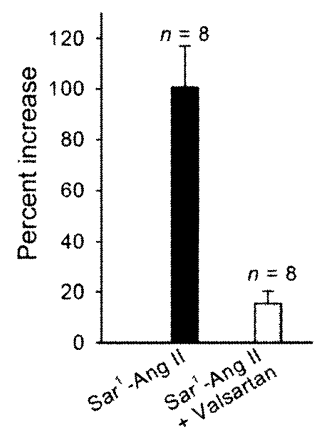

図2 Sar'-Ang II による $\mathrm{I}_{\mathrm{ks}}$ の増大には $\mathrm{AT}_{1}$ 受容体が関与している $\mathrm{A}$ ：バルサルタン存在下におけるSar'-Ang II の $\mathrm{I}_{\mathrm{ks}}$ に対する作用. $2,000 \mathrm{msec}$ の脱分極パルス (テスト電位, $+30 \mathrm{mV}$ )を 20 秒に 1 回の割合で与えて $\mathrm{I}_{\mathrm{Ks}}$ を活性化し， $-50 \mathrm{mV}$ の保持電位で記録された $\mathrm{I}_{\mathrm{Ks}}$ tail currentの大きさ をプロットした。バルサルタン $(1 \mu \mathrm{mol} / \mathrm{L})$ およびSar-Ang II $(100 \mathrm{nmol} / \mathrm{L})$ の投与期間は水平線で示した.

$\mathrm{B} ：$ バルサルタン非存在下ならびに存在下でのSar-Ang II の $\mathrm{I}_{\mathrm{Ks}}$ に対する増 加率.

〔文献19)上り引用改変〕
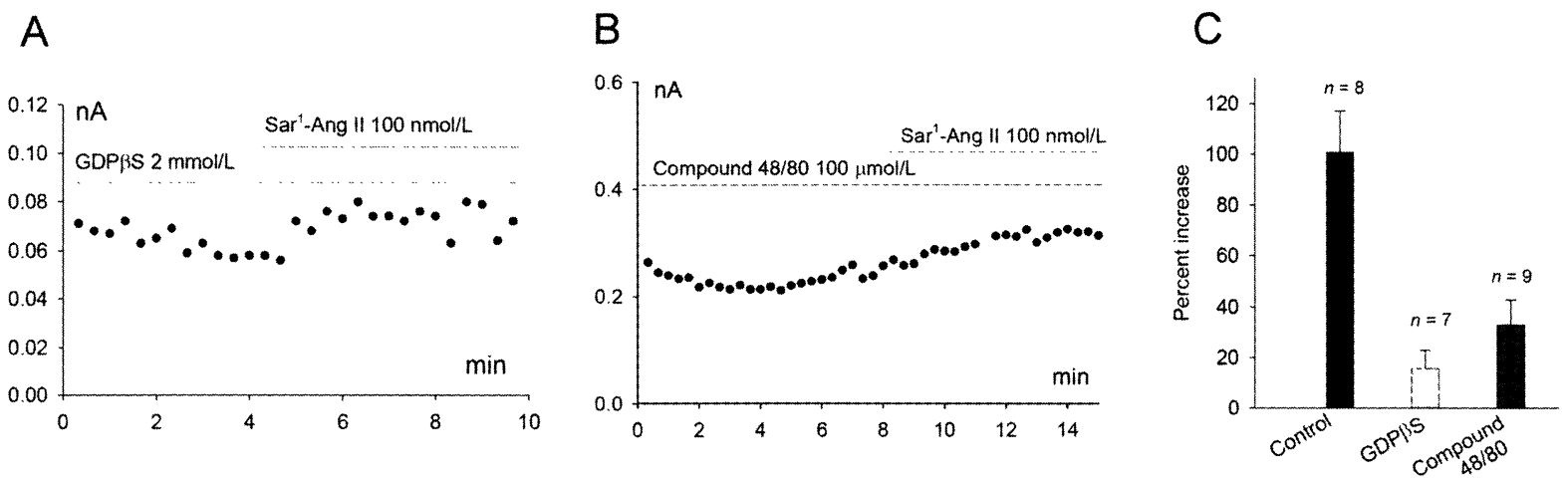

図3 Sar'-Ang II によるI ks の増大にはGqタンパク質，ホスホリパーゼC(PLC)が関与している

A，B : GDP $\beta S(2 \mathrm{mmol} / \mathrm{L} ; \mathrm{A})$ もしくはcompound 48/80(100 $\mu \mathrm{mol} / \mathrm{L} ； \mathrm{~B})$ をパッチ電極に加え細胞内に負荷したとき のSar'-Ang IIの $\mathrm{I}_{\mathrm{Ks}}$ に対する作用.

$\mathrm{C}: \mathrm{GDP} \beta \mathrm{S}(2 \mathrm{mmol} / \mathrm{L})$ もしくは compound 48/80(100 $\mu \mathrm{mol} / \mathrm{L})$ を細胞内負荷したときの Sar ${ }^{1}$-Ang $I$ の $\mathrm{I}_{\mathrm{Ks}}$ に対する増加率.

コントロール時の増加率と比較すると有意に $(\mathrm{P}<0.05)$ 減少している.

〔文献19)より引用改変〕

細胞を含む多くの細胞系において示されている ${ }^{20)}$. よって，このGq-PLC-PKC系のかかわりについて検 討を行った. Gq タンパク質の機能を非水解性 GDP アナログである guanosine 5’-O-(2-thiodiphosphate) $(\mathrm{GDP} \beta \mathrm{S}, 2 \mathrm{mmol} / \mathrm{L})$ を細胞内に負荷して抑制する と (パッチ電極を介して), Sar'-Ang II $(100 \mathrm{nmol} / \mathrm{L})$
による $\mathrm{I}_{\mathrm{Ks}}$ の増加率は有意に減少した（増加率， $15.9 \pm 7.0 \% ; \mathrm{n}=7 ; \mathrm{P}<0.05$ : 図3A，C).また, PLCの機能を compound 48/80 $(100 \mu \mathrm{mol} / \mathrm{L})$ で抑制 した細胞においても, 同様に $\mathrm{Sar}^{1}$ - Ang II $(100 \mathrm{nmol} / \mathrm{L})$ による $\mathrm{I}_{\mathrm{Ks}}$ の増加率は大きく低下した (増加率, $32.9 \pm 9.9 \% ; \mathrm{n}=9 ; \mathrm{P}<0.05$ : 図3B, C). 


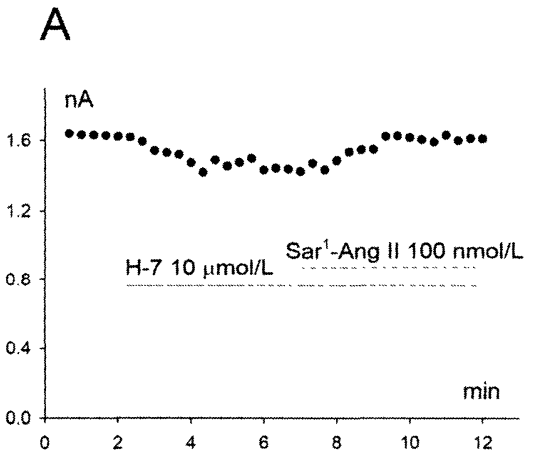

B

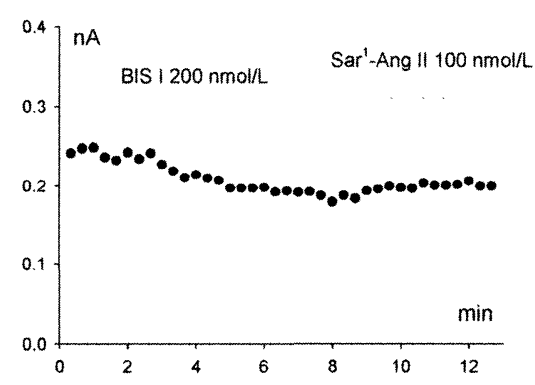

C

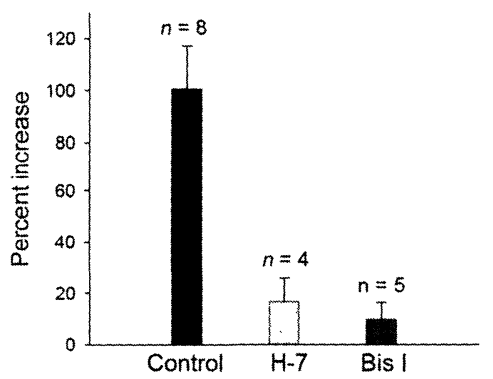

図4 PKC 阻害剤の存在下における Sar-Ang $\mathbb{I}$ の $\mathrm{I}_{\mathrm{Ks}}$ に対する作用

A, B ：H-7 $(10 \mu \mathrm{mol} / \mathrm{L} ; \mathrm{A})$ もしくはBIS I $(200 \mathrm{nmol} / \mathrm{L} ; \mathrm{B})$ を細胞灌流液に加えたときの $\operatorname{Sar}^{1}-\mathrm{Ang}$ II $\mathrm{I}_{\mathrm{Ks}} に$ に対する効果.

$\mathrm{C}: \mathrm{H}-7(10 \mu \mathrm{mol} / \mathrm{L} ; \mathrm{A})$ もしくはBIS I $(200 \mathrm{nmol} / \mathrm{L} ; \mathrm{B})$ 存在下の Sar ${ }^{1}-\mathrm{Ang}$ II の $\mathrm{I}_{\mathrm{Ks}}$ に対する増加率. コントロール時の増 加率と比較すると有意に減少している.

〔文献 19)より引用改変〕

これらの実験結果は, Sar'-Ang II $(100 \mathrm{nmol} / \mathrm{L})$ によ る $\mathrm{I}_{\mathrm{Ks}}$ の増大に $\mathrm{Gq}$ タンパク質, PLCのかかわりを支 持するものである.

PLC は細胞膜ホスファチジルイノシトール 4, 5ビスリン酸 $\left(\mathrm{PIP}_{2}\right)$ を分解してジアシルグリセロール (DAG) とイノシトール三リン酸 $\left(\mathrm{IP}_{3}\right)$ の 2 つの二次 メッセンジャーを産生し，これらはそれぞれPKCの 活性化と細胞内 $\mathrm{Ca}^{2+}$ 濃度の上昇を引き起こす。また， モルモット心筋細胞にパッチクランプ法を適用した 実験においてはPKCの活性化と細胞内 $\mathrm{Ca}^{2+}$ 濃度の 上昇はいずれも $\mathrm{I}_{\mathrm{Ks}}$ を増加することが明らかにされて いる ${ }^{21)}$. 図4A，BはそれぞれPKCの阻害剂である H-7 (1-(5-isoquinolinesulfonyl)-2-methylpiperazine, $10 \mu \mathrm{mol} / \mathrm{L})$ およびBIS I (bisindolylmaleimide I, $200 \mathrm{nmol} / \mathrm{L}$ ) 存在下での Sar-Ang II の $\mathrm{I}_{\mathrm{Ks}}$ に及ほす効 果を示す.H-7およびBIS Iは，いずれも Sar'-Ang IIによる $\mathrm{I}_{\mathrm{Ks}}$ の増大反応を大きく抑制し, $\mathrm{I}_{\mathrm{Ks}}$ の増加率 は H-7 存在下では $16.0 \pm 9.2 \% ; \mathrm{n}=4 ; \mathrm{P}<0.05$ (図4A,C), BIS I存在下では $9.8 \pm 6.4 \% ; \mathrm{n}=5$; $\mathrm{P}<0.05$ (図4B,C)であった。これらの実験結果は, Sar-Ang II による $\mathrm{I}_{\mathrm{Ks}}$ の増大反応にPKCの活性化が かかわっていることを強く示唆する.

PKCのかかわりをさらに検討する目的で, PKC をあらかじめ phorbol 12-myristate 13-acetate(PMA) JPN. J. ELECTROCARDIOLOGY Vol. 27 No. 22007 もしくは1-oleoyl-2-acetyl-sn-glycerol (OAG) で活性 化した状態でSar-Ang II の $\mathrm{I}_{\mathrm{Ks}}$ に及ぼす効果を検討 した。図 $5 \mathrm{~A}, \mathrm{~B}$ に示すようにPMA $(300 \mathrm{nmol} / \mathrm{L})$ も しくは OAG $(20 \mu \mathrm{mol} / \mathrm{L})$ を細胞灌流液に添加すると, $\mathrm{PKC}$ の活性化を介して $\mathrm{I}_{\mathrm{Ks}}$ が徐々に増大していっ た ${ }^{21)}$. その増大反応が定常状態に達した時点でさら にSar1-Ang II を細胞灌流液に加えてその $\mathrm{I}_{\mathrm{Ks}}$ に及ほ す効果を調べたところ，図5Cに示すように増大反 応の程度は大きく減少した (PMA, $7.7 \pm 2.3 \%$; $\mathrm{n}=7, \mathrm{OAG}, 10.1 \pm 1.5 \% ; \mathrm{n}=9)$. すなわち, PKC 活性化状態ではSar-Ang II の $\mathrm{I}_{\mathrm{Ks}}$ に対する増大 反応は減弱したことが示され，この実験結果も $\mathrm{PKC}$ の活性化のかかわりを支持する.

細胞内の $\mathrm{Ca}^{2+}$ のかかわりについては, EGTA (ethylene glycol-bis ( $\beta$-aminoethyl ether)-N,N,N',N' tetraacetic acid, $5 \mathrm{mmol} / \mathrm{L})$ の代わりにBAPTA (1,2-bis (O-aminophenoxy) -ethane-N,N,N',N' tetraacetic acid, $20 \mathrm{mmol} / \mathrm{L}$ )を細胞内液に加えて検 討したが, Sar'-Ang II による $\mathrm{I}_{\mathrm{Ks}}$ の増加率に有意な変 化は生じなかった(増加率, $76.0 \pm 11.5 \% ; \mathrm{n}=4$ ). よって, 細胞内 $\mathrm{Ca}^{2+}$ は重要な役割を果たしていない と考えられた。 また， $\mathrm{I}_{\mathrm{Ks}}$ はcAMP-プロテインキナー ゼ A (PKA) 系の活性化で大きく増大することが知られ ているため ${ }^{11)}, \mathrm{AT}_{1}$ 受容体による $\mathrm{I}_{\mathrm{Ks}}$ の増大機構への 
A

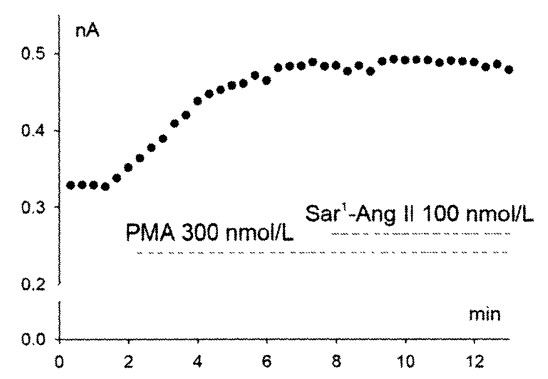

B

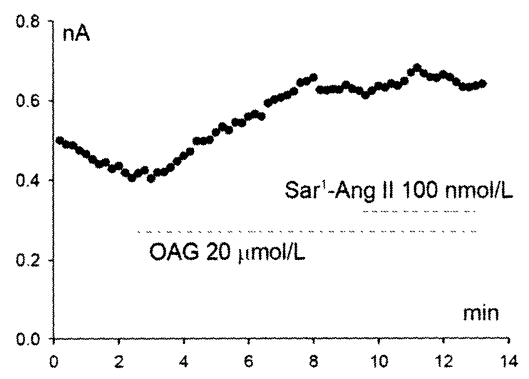

C

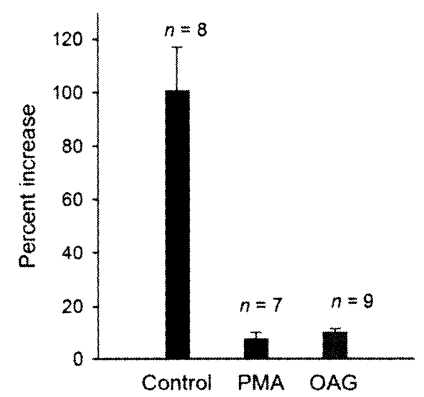

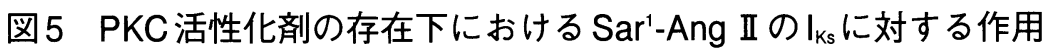

A, B:PMA ( $300 \mathrm{nmol} / \mathrm{L} ; \mathrm{A})$ もしく $\mathrm{OAG}(20 \mu \mathrm{mol} / \mathrm{L} ; \mathrm{B})$ 存在下 (細胞灌流液)における Sar-Ang II の $\mathrm{I}_{\mathrm{Ks}}$ に対する効果.

$\mathrm{C}: \mathrm{PMA}(300 \mathrm{nmol} / \mathrm{L})$ もしくは $\mathrm{OAG}(20 \mu \mathrm{mol} / \mathrm{L})$ 存在下の Sar ${ }^{1}-\mathrm{Ang} I I$ の $\mathrm{I}_{\mathrm{ks}}$ に対する増加率. コントロール時の増加率と 比較すると有意に減少している.

〔文献19)上り用改変〕

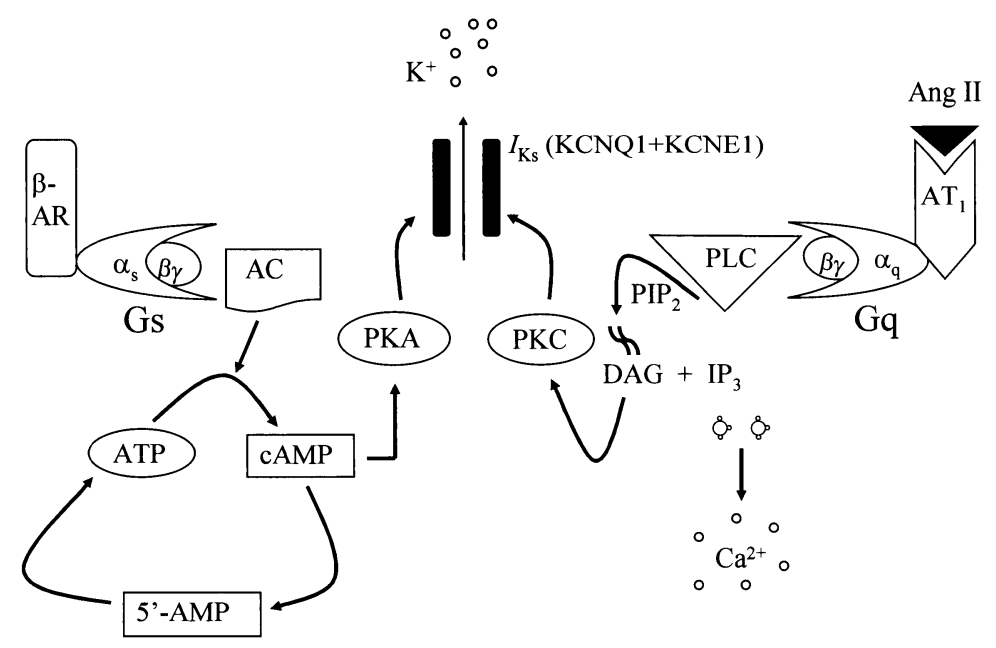

図6Ａng II（ならびにSar'-Ang II）によるI $\mathrm{Ks}_{\mathrm{s}}$ の増大作用にかか わる細胞内シグナル伝達機構

Ang II (ならびに Sar'-Ang II ) は AT ${ }_{1}$ 受容体-Gq-PLC-PKCを活性化して $\mathrm{I}_{\mathrm{Ks}}$ を増大させる。この系にPKA系はかかわっていない.

かかわりについて PKA 阻害剤であるKT5720を用い て検討した. Sar'-Ang II はKT5720 $(200 \mathrm{nmol} / \mathrm{L})$ 存 在下においても $\mathrm{I}_{\mathrm{Ks}}$ を同程度 $(90.7 \pm 6.4 \%, \mathrm{n}=5)$ に 増大させたため，PKAはかかわっていないことが示 唆された。すなわち， $\mathrm{AT}_{1}$ 受容体による $\mathrm{I}_{\mathrm{Ks}}$ の増大反 応において $\mathrm{PKC}$ 系と PKA系との間にクロストーク はないと考えられた(図6)。

\section{III. $A T_{1}$ 受容体刺激による活動電位の短縮と $\mathrm{AT}_{1}$ 受容体阻害薬による拮抗作用}

最後にSar'-Ang II のモルモット心房筋活動電位に 及ぼす作用について検討した。活動電位持続時間は $90 \%$ 再分極までの時間として計測した $\left(\mathrm{APD}_{90}\right)$. 図 7A は同一細胞から記録されたコントロール時, Sar'-Ang II $(100 \mathrm{nmol} / \mathrm{L})$ 投与時，ならびにその washout 時の活動電位を示す. 多数例の実験をまと 

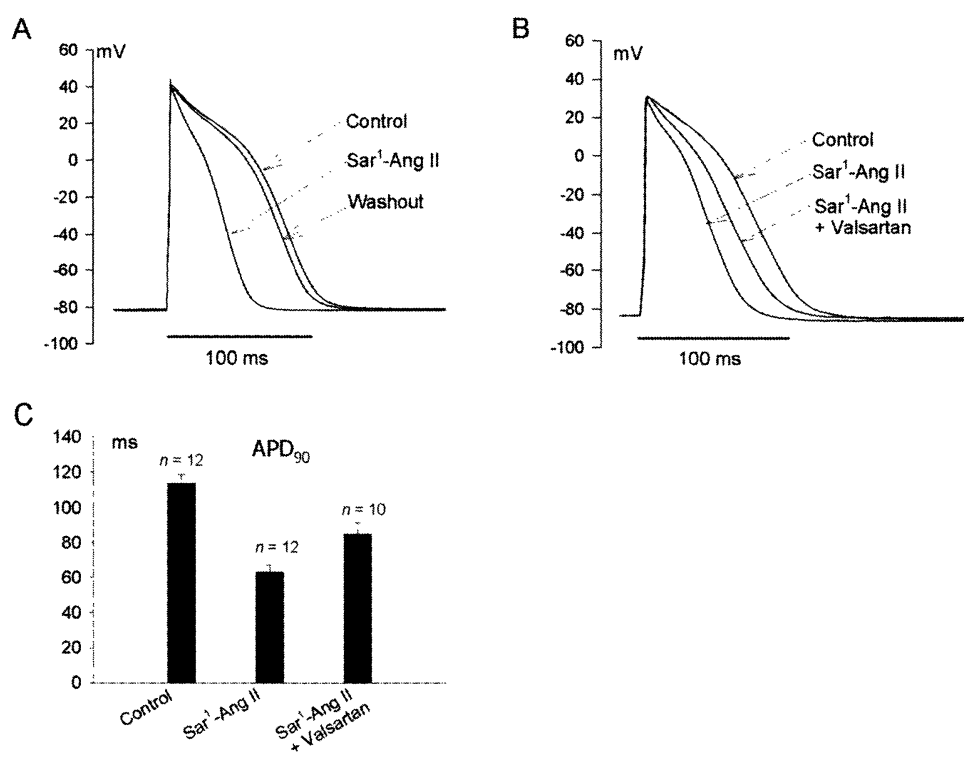

図7 モルモット心房筋細胞における Sar'-Ang II による活動電 位短縮作用とそれに対する $\mathrm{AT}_{1}$ 受容体遮断薬(バルサルタ ン)の拮抗作用

A : Sar ${ }^{1}$-Ang II の活動電位短縮作用. Sar'-Ang II $(100 \mathrm{nmol} / \mathrm{L})$ 投与前 (Control)，投与中 (Sar'-Ang II)，およびwashout 5 分後(Washout)に 記録された活動電位.

B : Sar -Ang II の活動電位短縮作用に対するバルサルタンの拮抗作用. Sar'-Ang II $(100 \mathrm{nmol} / \mathrm{L})$ 投与前 (Control), 投与中 (Sar-1'-Ang II ), お よびSar'-Ang II 存在下においてバルサルタン $(1 \mu \mathrm{mol} / \mathrm{L})$ 添加時 (Sar'Ang II +バルサルタン)に記録された活動電位.

C : Sar'-Ang II (100 nmol/L) 投与前 (Control), 投与中 (Sar'-Ang II ), お よびSar-Ang II +バルサルタン $(1 \mu \mathrm{mol} / \mathrm{L})$ 投与時 $\left(\mathrm{Sar}^{1}-\mathrm{Ang}\right.$ II +バル サルタン)の $\mathrm{APD}_{90}$.

〔文献19)上り引用改変〕

めると，コントロール時の $\mathrm{APD}_{90}$ は $113.1 \pm$ $8.8 \mathrm{msec} ; \mathrm{n}=12$ であり, Sar-Ang II $(100 \mathrm{nmol} / \mathrm{L})$ 投与時には $63.1 \pm 5.8 \mathrm{msec}$ であり, Sar'-Ang II によ り $\mathrm{APD}_{90}$ は約 $55 \%$ に短縮した (図7B). その短縮効 果はSar'-Ang II 細胞灌流液から washoutすること によりほぼ完全に消失した（図7A）。一方，Sar ${ }^{1}$ Ang IIにより短縮した活動電位はバルサルタン (1 $\mu \mathrm{mol} / \mathrm{L})$ を加えることにより，88.1 $\pm 7.0 \mathrm{msec}$ ； $\mathrm{n}=10$ まで回復した(図7B,C).

\section{IV. 考察}

本実験結果により，モルモット心房筋細胞におい
てAng II は AT 1 受容体-Gタンパク質 $(\mathrm{Gq})$-ホスホリ パーゼC (PLC)-プロテインキナーゼC (PKC) 系を活 性化して $\mathrm{I}_{\mathrm{Ks}}$ を増大させ，それに伴い APDを大きく 短縮させることが明らかとなった．また， $\mathrm{AT}_{1}$ 受容 体遮断薬 (バルサルタン)は, Ang IIのもつ活動電位 短縮作用に対して拮抗的にはたらいた ${ }^{19)}$.

心房細動に伴う電気的リモデリングは心房筋有効 不応期 (atrial effective refractory period, AERP)の 短縮を特徴とし, 発症後早期 (数時間後以内) から出 現する。その主なメカニズムとして $\mathrm{I}_{\mathrm{Ca}, \mathrm{L}}$ チャネルの downregulationがあげられている (図8)。一方, 構 造的リモデリングは心房の線維化を主体とし，その 


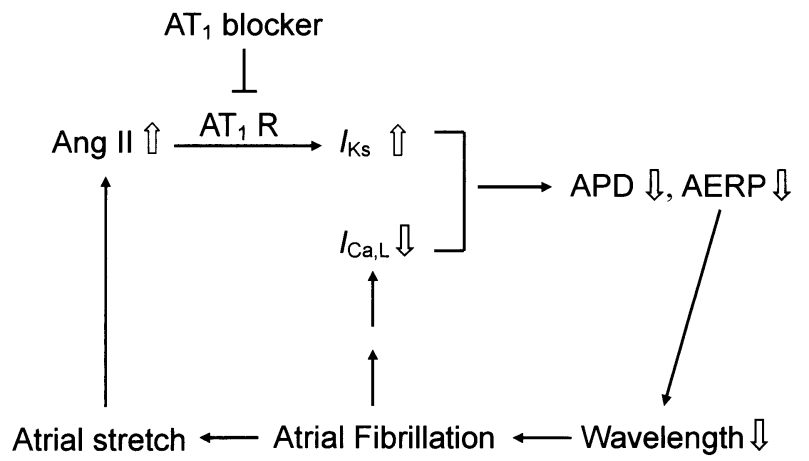

図8 心房筋における電気的リモデリングにおける $A T_{1}$ 受容体による $I_{\mathrm{ks}}$ 増大作用の関与

発生の時間経過は比較的遅く(心房細動発生後数週 間以降)，また $\mathrm{AT}_{1}$ 受容体遮断薬がその発生予防効 果をもつことが報告されている，よって，構造的リ モデリングには $\mathrm{AT}_{1}$ 受容体刺激に伴う細胞内シグナ ル分子 (extracellular-signal regulated kinase, ERK 等)の活性化がかかわっていると考えられている22, 23). 動物実験モデルにおいて比較的短時間 (180分)の高 頻度心房ペーシングにより惹起された心房筋有効不 応期の短縮に対しても $\mathrm{AT}_{1}$ 受容体遮断薬が抑制効果 をもつことが示されており，心房筋の電気的リモデ リングの発生にも $\mathrm{AT}_{1}$ 受容体がかかわっていること が示唆されている ${ }^{24)}$. また, 心房細動の除細動後の 再発を検討した臨床スタディにおいてアミオダロン 単独投与群とアミオダロン $+\operatorname{irbesartan}\left(\mathrm{AT}_{1}\right.$ 遮断薬 $)$ 投与群を比較すると，アミオダロン + irbesartan投 与群の方が除細動後の早期の再発が有意に抑制され ることも明らかにされている ${ }^{18)}$ 。この結果もまた心 房細動の早期に起こる電気的リモデリングに $\mathrm{AT}_{1}$ 受 容体が関与していることを示唆している。この $\mathrm{AT}_{1}$ 受容体を介した心房筋電気的リモデリング (AERP の短縮)の1つのメカニズムとして，本実験で示され た $\mathrm{AT}_{1}$ 受容体による心房筋活動電位に対する急性短 縮作用 $\left(\mathrm{I}_{\mathrm{Ks}}\right.$ の増大を介する)がかかわっていると考え られる(図8).なお，Ang IIのソースの一つとして， 心筋細胞の伸展に伴い心筋細胞自身から放出された Ang IIが，オートクラインもしくはパラクラインと
して心筋細胞の Ang II 受容体に作用していることも 考えられる ${ }^{25)}$ 26).

終わりに，モルモット心房筋細胞で明らかにされ た $\mathrm{AT}_{1}$ 受容体による $\mathrm{I}_{\mathrm{Ks}}$ の増大反応ならびに活動電位 短縮作用がヒト心房筋細胞で観察されるかについて の検討は, 今後の興味ある研究課題と思われる.

\section{〔文献〕}

1 ) Sanguinetti MC, Jurkiewicz NK : Two components of cardiac delayed rectifier $\mathrm{K}^{+}$current. Differential sensitivity to block by class III antiarrhythmic agents. J Gen Physiol, 1990 ; 96 : 195 215

2 ) Sanguinetti MC, Jurkiewicz NK : Delayed rectifier outward $\mathrm{K}^{+}$current is composed of two currents in guinea pig atrial cells. Am J Physiol, $1991 ; 260$ : H393 H399

3 ) Wang Z, Fermini B, Nattel S : Delayed rectifier outward current and repolarization in human atrial myocytes. Circ Res, $1993 ; 73: 276 \sim 285$

4 ) Gintant GA : Two components of delayed rectifier current in canine atrium and ventricle. Does $\mathrm{I}_{\mathrm{Ks}}$ play a role in the reverse rate dependence of class III agents? Circ Res, $1996 ; 78: 26 \sim 37$

5 ) Li GR, Feng J, Yue L, Carrier M, Nattel S : Evidence for two components of delayed rectifier $\mathrm{K}^{+}$current in human ventricular myocytes. Circ Res, $1996 ; 78: 689 \sim$ 696

6 ) Bosch RF, Gaspo R, Busch AE, Lang HJ, Li GR, Nattel S : Effects of the chromanol 293B, a selective blocker of the slow, component of the delayed rectifier $\mathrm{K}^{+}$current, on repolarization in human and guinea pig ventricular myocytes. Cardiovasc Res, 1998 ; 38 : $441 \sim 450$

7 ) Bosch RF, Schneck AC, Csillag S, Eigenberger B, Gerlach U, Brendel J, Lang HJ, Mewis C, Gögelein H, Seipel L, Kühlkamp V : Effects of the chromanol HMR 1556 on potassium currents in atrial myocytes. NaunynSchmiedebergs Arch Pharmacol, $2003 ; 367: 281 \sim 288$

8 ) Ding WG, Toyoda F, Matsuura $\mathrm{H}$ : Regulation of cardiac $\mathrm{I}_{\mathrm{Ks}}$ potassium current by membrane phosphatidylinositol 4,5-bisphosphate. J Biol Chem, 2004 ; 279 : 50726 50734

9 ) Matsuura H, Ehara T, Imoto Y : An analysis of the delayed outward current in single ventricular cells of the guinea-pig. Pflügers Arch, $1987 ; 410: 596 \sim 603$

10) Harvey RD, Hume JR : Autonomic regulation of delayed rectifier $\mathrm{K}^{+}$current in mammalian heart involves $\mathrm{G}$ proteins. Am J Physiol, 1989 ; 257 : H818 H823

11) Yazawa K, Kameyama M : Mechanism of receptor- 
mediated modulation of the delayed outward potassium current in guinea-pig ventricular myocytes. J Physiol, $1990 ; 421: 135 \sim 150$

12) Tohse N, Nakaya H, Kanno M : $\alpha_{1}$-Adrenoceptor stimulation enhances the delayed rectifier $\mathrm{K}^{+}$current of guinea pig ventricular cells through the activation of protein kinase C. Circ Res, $1992 ; 71: 1441 \sim 1446$

13) Matsuura H, Tsuruhara Y, Sakaguchi M, Ehara T : Enhancement of delayed rectifier $\mathrm{K}^{+}$current by $\mathrm{P}_{2^{-}}$ purinoceptor stimulation in guinea-pig atrial cells. $\mathrm{J}$ Physiol, 1996 ; $490: 647 \sim 658$

14) Wijffels MC, Kirchhof CJ, Dorland R, Allessie MA : Atrial fibrillation begets atrial fibrillation. A study in awake chronically instrumented goats. Circulation, 1995 ; $92: 1954 \sim 1968$

15) Allessie M, Ausma J, Schotten U : Electrical, contractile and structural remodeling during atrial fibrillation. Cardiovasc Res, $2002 ; 54: 230 \sim 246$

16) Nattel $\mathrm{S}:$ New ideas about atrial fibrillation 50 years on. Nature, 2002 ; $415: 219 \sim 226$

17) Chen YH, Xu SJ, Bendahhou S, Wang XL, Wang Y, Xu WY, Jin HW, Sun H, Su XY, Zhuang QN, Yang YQ, Li YB, Liu Y, Xu HJ, Li XF, Ma N, Mou CP, Chen Z, Barhanin J, Huang W : KCNQ1 gain-of-function mutation in familial atrial fibrillation. Science, $2003 ; 299$ : $251 \sim 254$

18) Madrid AH, Bueno MG, Rebollo JM, Marin I, Pena G, Bernal E, Rodriguez A, Cano L, Cano JM, Cabeza P, Moro $\mathrm{C}$ : Use of irbesartan to maintain sinus rhythm in patients with long-lasting persistent atrial fibrillation : a prospective and randomized study. Circulation, 2002 ; $106: 331 \sim 336$

19) Zankov DP, Omatsu-Kanbe M, Isono T, Toyoda F, Ding WG, Matsuura H, Horie M : Angiotensin II potentiates the slow component of delayed rectifier $\mathrm{K}^{+}$current via the $\mathrm{AT}_{1}$ receptor in guinea pig atrial myocytes. Circulation, $2006 ; 113: 1278 \sim 1286$

20) Touyz RM, Schiffrin EL : Signal transduction mechanisms mediating the physiological and pathophysiological actions of angiotensin II in vascular smooth muscle cells. Pharmacol Rev, 2000 ; 52 : 639 672

21) Tohse N, Kameyama M, Irisawa $\mathrm{H}$ : Intracellular $\mathrm{Ca}^{2+}$ and protein kinase $\mathrm{C}$ modulate $\mathrm{K}^{+}$current in guinea pig heart cells. Am J Physiol, 1987 ; 253 : H1321 H1324

22) Kumagai K, Nakashima H, Urata H, Gondo N, Arakawa $\mathrm{K}$, Saku K : Effects of angiotensin II type I receptor antagonist on electrical and structural remodeling in atrial fibrillation. J Am Coll Cardiol, $2003 ; 41$ : 2197 2204

23) Goette A, Staack T, Rocken C, Arndt M, Geller JC, Huth C, Ansorge S, Klein HU, Lendeckel U : Increased expression of extracellular signal-regulated kinase and angiotensin-converting enzyme in human atria during atrial fibrillation. J Am Coll Cardiol, 2000 ; 35 : 1669 1677

24) Nakashima H, Kumagai K, Urata H, Gondo N, Ideishi M, Arakawa $\mathrm{K}$ : Angiotensin II antagonist prevents electrical remodeling in atrial fibrillation. Circulation, $2000 ; 101: 2612 \sim 2617$

25) Sadoshima J, Xu Y, Slayter HS, Izumo S : Autocrine release of angiotensin II mediates stretch-induced hypertrophy of cardiac myocytes in vitro. Cell, 1993 ; 75 : $977 \sim 984$

26) Yamazaki T, Komuro I, Kudoh S, Zou Y, Shiojima I, Mizuno T, Takano H, Hiroi Y, Ueki K, Tobe K, Kadowaki T, Nagai R, Yazaki Y : Mechanical stress activates protein kinase cascade of phosphorylation in neonatal rat cardiac myocytes. J Clin Invest, 1995 ; 96 : $438 \sim 446$ 